\title{
PENERAPAN KEBIJAKAN KAWASAN TANPA ROKOK DI TAMAN SEMPUR KOTA BOGOR
}

\author{
Amelia Triningtias $^{1}$, Eko Sugiyanto ${ }^{2}$ \\ ${ }^{1}$ Program Studi Ilmu Politik, Universitas Nasional \\ ${ }^{2}$ Program Studi Pascasarjana, Universitas Nasional \\ email : ameliatriningtias53@gmail.com, ekoantodr@gmail.com \\ Korespondensi : ekoantodr@gmail.com
}

\begin{abstract}
This research is based on the low awareness of the public about the dangers of smoking and smoking bans in public places despite the Bogor City Regulation No. 10 of 2018 concerning No-Smoking Areas. Considering that Sempur Park is an important and beneficial public facility for the people of Bogor City, this research aims to find out the factors that support the successful implementation of the non-smoking area policy in Sempur Park. The theory used is the Mazmanian and Sabatier implementation model, while the research method uses a qualitative approach with descriptive research type. Based on the results of research and discussion, it was concluded that the application of the no-smoking area policy in Sempur Park was not yet fully effective. Therefore it is necessary to evaluate the application of nonsmoking area policies in Taman Sempur, both from the dimensions of the problem characteristics, policy characteristics, and the policy environment.
\end{abstract}

Keywords: policy implementation, area without cigarettes, sempur park, bogor city, application

\begin{abstract}
Abstrak
Penelitian ini didasari oleh rendahnya kesadaran masyarakat tentang bahaya merokok dan larangan merokok di tempat-tempat umum walaupun telah ada Peraturan Kota Bogor No. 10 tahun 2018 tentang Kawasan Tanpa Rokok. Mengingat Taman Sempur merupakan fasilitas publik yang penting dan bermanfaat bagi masyarakat Kota Bogor, maka penelitian ini bertujuan untuk mengetahui faktor-faktor yang menunjang keberhasilan implementasi kebijakan kawasan tanpa rokok di Taman Sempur. Teori yang digunakan adalah model implementasi Mazmanian dan Sabatier, sedangkan metode penelitian menggunakan pendekatan kualitatif dengan jenis penelitian deskriptif. Berdasarkan hasil penelitian dan pembahasan disimpulkan bahwa penerapan kebijakan kawasan tanpa rokok di Taman Sempur belum sepenuhnya efektif. Oleh karenanya perlu evaluasi penerapan kebijakan kawasan tanpa rokok di Taman Sempur, baik dari dimensi karakteristik masalah, karakteristik kebijakan, dan lingkungan kebijakan.
\end{abstract}

Kata kunci: implementasi kebijakan, kawasan tanpa rokok, taman sempur, kota bogor, penerapan 


\section{PENDAHULUAN}

Hak untuk menghirup udara bersih tanpa paparan asap rokok telah menjadi perhatian dunia. WHO memprediksi penyakit yang berkaitan dengan rokok akan menjadi masalah kesehatan di dunia. Dari tiap 10 orang dewasa yang meninggal,1 orang diantaranya meninggal karena disebabkan asap rokok. Dari data WHO tahun 2004 ditemui sudah mencapai 5 juta kasus kematian setiap tahunnya serta $70 \%$ terjadi di Negara berkembang, termasuk didalamnya di Asia dan Indonesia. Di tahun 2025 nanti, saat jumlah perokok dunia sekitar 650 juta orang maka akan ada 10 juta kematian per tahun. Tanpa adanya upaya pencegahan dalam pengurangan konsumsi rokok, maka WHO memprediksi pada tahun 2025 jumlah perokok akan meningkat menjadi 1,6 miliar. Indonesia berada pada posisi kelima di dunia dalam konsumsi rokok, ketiga dalam jumlah perokok dan memiliki jumlah pabrik rokok terbanyak di dunia.

Rendahnya kesadaran masyarakat tentang bahaya merokok menjadi alasan sulitnya penetapan Kawasan Tanpa Rokok (KTR), yang ditunjukkan dengan mulai merokok pada kelompok usia 5-9 tahun. Konsumsi rokok paling rendah terjadi pada kelompok umur 15-24 tahun dan kelompok umur 75 tahun ke atas. Hal ini berarti kebanyakan perokok adalah generasi muda atau usia produktif. Selanjutnya, pada daerah pedesaan, jumlah batang rokok yang dikonsumsi lebih banyak dibanding daerah perkotaan. Penetapan Kawasan Tanpa Rokok sebenarnya selama ini telah banyak diupayakan oleh berbagai pihak baik lembaga pemerintah maupun swasta dan masyarakat. Namun pada kenyataannya upaya yang telah dilakukan tersebut jauh tertinggal dibandingkan dengan penjualan, periklanan dan atau penggunaan rokok.

Agar permasalahan dan kondisi tersebut di atas dapat dikendalikan maka perlu dilakukan upaya pengamanan terhadap bahaya merokok melalui penetapan Kawasan Tanpa Rokok dan juga membatasi ruang gerak para perokok. Penetapan Kawasan Tanpa Rokok merupakan upaya perlindungan untuk masyarakat terhadap risiko ancaman gangguan kesehatan karena lingkungan tercemar asap rokok. Penetapan Kawasan Tanpa Rokok ini perlu diselenggarakan di fasilitas pelayanan kesehatan, tempat proses belajar mengajar, tempat anak bermain, tempat ibadah, angkutan umum, tempat kerja, tempat umum dan tempat lain yang ditetapkan, untuk melindungi masyarakat yang ada dari asap rokok. Beberapa peraturan telah diterbitkan sebagai landasan hukum dalam pengembangan Kawasan Tanpa Rokok, antara lain: Undang-Undang Republik Indonesia Nomor 36 Tahun 2009 tentang Kesehatan, Peraturan Pemerintah Republik Indonesia No. 19 Tahun 2003 tentang Pengamanan Rokok bagi Kesehatan, Instruksi Menteri Kesehatan Nomor 84/Menkes/Inst/II/2002 tentang Kawasan Tanpa Rokok di Tempat Kerja dan Sarana Kesehatan, Instruksi Menteri Pedidikan dan Kebudayaan RI Nomor 4/U/1997 tentang Lingkungan Sekolah Bebas Rokok, dan Instruksi Menteri Kesehatan Republik Indonesia Nomor 161/Menkes/Inst/III/1990 tentang Lingkungan Kerja Bebas Asap Rokok.

Dalam perkembangannya Kementerian Dalam Negeri (Kemendagri) melalui Direktur Jenderal Bina Pembangunan Daerah, mengingatkan Pemerintah Daerah 
(Pemda) agar menyusun dan mempercepat penerbitan kebijakan tentang Kawasan Tanpa Rokok (KTR), serta menerapkan aturan KTR di sekolah. Kewajiban Pemda menerapkan Kawasan Tanpa Rokok sebagaimana diatur dalam Undang-Undang Nomor 36 Tahun 2009 tentang Kesehatan, pasal 115 ayat (2), Peraturan Pemerintah Nomor 109 Tahun 2012 tentang Pengamanan Bahan yang Mengandung Zat Adiktif Berupa Tembakau Bagi Kesehatan dan Peraturan Bersama Menteri Kesehatan dan Menteri Dalam Negeri Nomor 188/Menkes/Pb/I2011 Nomor 2011 tentang Pedoman Pelaksanaan Kawasan Tanpa Rokok. Lebih lanjut Direktur Jenderal Bina Pembangunan Daerah mengingatkan Pemda perlu menyusun dan mempercepat penerbitan kebijakan tentang KTR baik berupa Peraturan Daerah maupun Peraturan Kepala Daerah serta menerapkan aturan KTR di sekolah. Pemda perlu memperkuat upaya promotif dan preventif melalui kegiatan penyuluhan dan edukasi secara berkelanjutan bagi anak-anak dan remaja usia sekolah berkaitan dengan dampak negatif akibat bahaya rokok. Pemda perlu mengefektifkan pelibatan peran tokoh masyarakat, tokoh agama, dan tokoh adat setempat dalam mengkampanyekan kebijakan tentang KTR, serta Pemda perlu menyediakan tempat khusus untuk merokok berupa ruang terbuka yang berhubungan langsung dengan udara luar. Yayasan Lembaga Konsumen Indonesia (YLKI) menilai kawasan tanpa rokok menjadi kebutuhan mutlak untuk melindungi masyarakat dari paparan asap rokok agar tidak menjadi perokok pasif, sebab Indonesia sudah mengalami darurat kanker karena prevalensi kanker semakin meningkat. Riset Kesehatan Dasar 2013 menyatakan prevalensi kanker 1,4 persen, tetapi Riset Kesehatan Dasar 2018 menyebutkan prevalensi kanker menjadi 1,8 persen.

Dari kota-kota yang ada di Indonesia, Kota Bogor merupakan salah satu kota di Jawa Barat yang telah menerapkan Kawasan Tanpa Rokok. Kota Bogor menjadi salah satu kota percontohan dalam penerapan Kawasan Tanpa Rokok, di mana masyarakatnya 90\% mendukung Kota Bogor sebagai kota bebas asap rokok. Meskipun demikian, dari data Dinas Kesehatan Kota Bogor tahun 2017, masih terdapat sebanyak 446.325 orang $(44,5 \%)$ dari jumlah penduduk Kota Bogor adalah perokok. Jika dirinci, 32\% adalah orang yang merokok setiap hari, 5,6\% yang merokok tidak secara rutin, dan 6,9\% merupakan mantan perokok. Oleh karena itu, Kebijakan Kawasan Tanpa Rokok di Kota Bogor yang telah berlangsung kurang lebih sebelas tahun sejak diterbitkannya Peraturan Daerah Kota Bogor Nomor 12 Tahun 2009 tentang Kawasan Tanpa Rokok, kemudian diubah menjadi Peraturan Daerah Nomor 10 Tahun 2018 tentang Kawasan Tanpa Rokok.

Dari sekian banyak kawasan yang melanggar Perda Kota Bogor Nomor 10 Tahun 2018 tentang Kawasan Tanpa Rokok adalah Taman Sempur. Padahal Taman Sempur merupakan salah satu ruang hijau terbuka yang harus bebas asap rokok. Sebagai Taman Ikonik Kota Hujan, Taman Sempur yang terletak di Jl. Sempur Kaler No.4, Sempur, Kecamatan Bogor Tengah, Kota Bogor, merupakan kebanggaan masyarakat Kota Bogor. Berdasarkan pengamatan peneliti, masih ada masyarakat atau pengunjung Taman Sempur yang merokok di sembarang tempat meskipun sudah ada rambu-rambu larangan merokok. Tidak semua pengunjung Taman Sempur mempedulikan dan mau mematuhi aturan tersebut. Padahal Taman Sempur sebagai fasilitas umum seharusnya tidak tercemari oleh asap rokok yang 
dapat mengganggu orang yang bukan perokok terutama pengunjung Taman Sempur lainnya. Banyak sekali terlihat perilaku pengunjung di Taman Sempur tidak menunjukkan adanya kepatuhan terhadap peraturan tersebut. Hal ini menunjukkan belum adanya tindak tegas dari pihak Pengelola Taman Sempur untuk menindak tegas pengunjung yang merokok di Taman Sempur, terutama oleh Park Ranger yang bertugas sebagai pengawas Lapangan Sempur, Taman Kaulinan, Taman Ekspresi, sehingga masyarakat atau pengunjung tidak merasa jera untuk terus melanggar aturan yang telah ditetapkan, bahkan masih terdapat pula pedagang rokok yang menjual dagangannya secara bebas di Taman Sempur. Padahal Sugiyanto (2018) menjelaskan bahwa: "Organisasi memerlukan pengendalian yang dilakukan dalam bentuk tata laksana, yaitu: manual, standar kriteria, norma, instruksi, dan lain-lain prosedur. Hal ini dapat dikatakan bahwa jika pengendalian di Taman Sempur dilakukan sesuai dengan tata laksana yang ada, maka pelanggaran-pelanggaran di Taman Sempur tidak akan terjadi.

Mengingat adanya pelanggaran kawasan tanpa rokok di Taman Sempur yang merupakan salah satu fasilitas umum yang sangat penting dan bermanfaat bagi masyarakat Kota Bogor, maka peneliti tertarik untuk mengambil judul "Penerapan Kebijakan Kawasan Tanpa Rokok di Taman Sempur Kota Bogor", dengan tujuan untuk mengetahui faktor-faktor yang menunjang keberhasilan penerapan kebijakan kawasan tanpa rokok di Taman Sempur Kota Bogor.

\section{METODE KAJIAN}

Penelitian ini menggunakan pendekatan kualitatif dengan jenis penelitian deskriptif, di mana fokus dari penelitian ini adalah Penerapan Kebijakan Kawasan Tanpa Rokok di Taman Sempur Kota Bogor. Dalam pemilihan informasi dilakukan secara purposive, terutama Kepala Sie Promosi Kesehatan dan Pemberdayaan Masyarakat Kota Bogor, Kepala Sie Operasional dan Pengendalian Satpol-PP Kota Bogor, Komandan Regu Park Ranger Taman Sempur, dan masyarakat yang berkujung ke Taman Sempur Kota Bogor. Sedangkan instrumen penelitian adalah peneliti sendiri, yang bersumber dari data primer dan sekunder, yang dianalisis dengan teknik triangulasi.

\section{TINJAUAN PUSTAKA Pengertian Kebijakan Publik}

Dalam Kamus Besar Bahasa Indonesia, kebijakan adalah rangkaian konsep dan asas yang menjadi garis besar dan dasar rencana dalam pelaksanaan suatu pekerjaan dalam mencapai tujuan atau sasaran (Lukman, 1995). Secara etimologis, menurut Dunn (2000) menjelaskan bahwa istilah kebijakan (policy) berasal dari bahasa Yunani, Sansekerta dan Latin. Dalam bahasa Yunani dan kebijakan disebut dengan polis yang berarti" negara-kota" dan sansakerta disebut dengan pur yang berarti "kota" serta dalam bahasa Latin disebut dengan politia yang berarti Negara. Friedrich (1971) menggemukakan bahwa pengertian kebijakan itu merupakan suatu arah tindakan yang diusulkan oleh kelompok, seseorang, atau juga pemerintah didalam suatu lingkungan tertentu yang memberikan hambatan-hambatan dan juga kesempatan-kesempatan terhadap suatu kebijakan yang diusulkan untuk bisa 
menggunakan serta juga mengatasi dalam rangka mencapai suatu tujuan, atau juga merealisasikan suatu sasaran atau juga maksud tertentu. Dunn mengemukakan kebijakan sebagai aturan tertulis yang merupakan suatu keputusan formal organisasi, yang mempunyai sifat yang mengikat, yang mengatur perilaku dengan tujuan untuk dapat menciptakan tatanilai baru dalam masyarakat. Kebijakan akan menjadi rujukan utama para anggota organisasi atau juga anggota masyarakat didalam berperilaku. Kebijakan pada umumnya memiliki sifat problem solving serta proaktif. Berbeda dengan Hukum (Law) dan juga Peraturan (Regulation), kebijakan lebih memiliki sifat adaptif dan intepratatif, walaupun kebijakan juga mengatur apa yang boleh, serta apa yang tidak boleh. Kebijakan juga diharapkan dapat bersifat umum namun tanpa menghilangkan ciri lokal yang spesifik. Kebijakan itu harus memberi peluang diintepretasikan sesuai dengan kondisi spesifik yang ada.

Banyak terminologi kebijakan publik (public policy) yang diutarakan para ahli. Easton memberikan definisi kebijakan publik sebagai the authoritative allocation of values for the whole society (pengalokasian nilai-nilai secara paksa kepada seluruh anggota masyarakat). Laswell dan Kaplan juga mengartikan kebijakan publik sebagai a projected program of goal, value, and practice (sesuatu program pencapaian tujuan, nilai-nilai dalam praktek-praktek yang terarah). Definisi ini menegaskan bahwa hanya pemilik otoritas dalam sistem politik (pemerintah) yang secara sah dapat berbuat sesuatu pada masyarakatnya dan pilihan pemerintah untuk melakukan sesuatu atau tidak melakukan sesuatu diwujudkan dalam bentuk pengalokasian nilai-nilai. Hal ini disebabkan karena pemerintah termasuk ke dalam "authorities in a political system" yaitu para penguasa dalam sistem politik yang terlibat dalam urusan sistem politik sehari-hari dan mempunyai tanggungjawab dalam suatu masalah tertentu dimana pada suatu titik mereka diminta untuk mengambil keputusan di kemudian hari kelak diterima serta mengikat sebagian besar anggota masyarakat selama waktu tertentu.

\section{Pengertian Implementasi}

Menurut Kamus Besar Bahasa Indonesia, penerapan adalah proses, cara, perbuatan melaksanakan (rancangan, keputusan, dan sebagainya). Sedangkan pengertian implementasi secara etimologis, menurut kamus Webster yang dikutip oleh Solichin Abdul Wahab (2012), berasal dari Bahasa Inggris yaitu to implement, yang dalam kamus besar Webster, "to implement" (mengimplementasikan) berarti to provide the means for carrying out (menyediakan sarana untuk melaksanakan sesuatu), dan to give practical effect to (untuk menimbulkan dampak terhadap sesuatu). Menurut Badudu dan Zain (1996), penerapan adalah hal, cara atau hasil. Sedangkan menurut Lukman, penerapan adalah mempraktekkan, memasangkan. Dengan demikian implementasi secara etimologis dapat disamakan dengan kata penerapan.

Implementasi kebijakan publik merupakan tahap yang krusial dalam proses kebijakan publik. Implementasi kebijakan pada dasarnya adalah cara agar sebuah kebijakan dapat mencapai tujuannya. Implementasi dilakukan setelah suatu kebijakan ditetapkan. Secara umum implementasi memiliki makna pelaksanaan undang-undang dimana berbagai aktor, organisasi, prosedur, dan teknik bekerja 
bersama-sama untuk menjalankan kebijakan dalam upaya untuk meraih tujuantujuan kebijakan atau program-program. Implementasi pada sisi lain merupakan fenomena yang kompleks yang mungkin dapat dipahami sebagai suatu proses, suatu keluaran (output) maupun sebagai suatu dampak (outcome). Misalnya, implementasi dikonseptualisasikan sebagai suatu proses atau serangkaian keputusan dan tindakan yang ditujukan agar keputusan-keputusan yang diterima oleh lembaga legislatif bisa dijalankan. Sementara Van Meter dan Van Horn (1975) mengatakan implementasi kebijakan merupakan tindakan-tindakan yang dilakukan oleh individu atau kelompok pemerintah maupun swasta yang diarahkan untuk mencapai tujuan-tujuan yang telah ditetapkan dalam keputusan-keputusan kebijkan sebelumnya. Ripley dan Franklin (1982) mendefinisikan implementasi merupakan apa yang terjadi setelah undang-undang ditetapkan dengan memberikan otoritas program, kebijakan, keuntungan (benefit), atau suatu jenis keluaran yang nyata (tangible output). Istilah implementasi menunjuk pada sejumlah kegiatan yang mengikuti pernyataan maksud tentang tujuan-tujuan program dan hasil-hasil yang diinginkan oleh para pejabat pemerintah. Implementasi mencakup tindakan-tindakan oleh berbagai aktor, kususnya para birokrat yang dimaksudkan untuk membuat program berjalan.

\section{Model Implementasi Kebijakan Mazmanian dan Sabatier}

Model implementasi yang dikembangkan Daniel Mazmanian dan Paul A. Sabatier pada tahun 1983 mengemukakan mengenai tiga kelompok variabel yang mempengaruhi keberhasilan implementasi kebijakan, yaitu karakteristik dari masalah (Trackability of the problem), karakteristik kebijakan (Ability of statute to structure implementation), dan lingkungan kebijakan (Non statutory variables affecting implementation). Model Mazmanian dan Sabatier disebut model Kerangka Analisis Implementasi (A framework for Implementation analysis).

Alasan penggunaan teori ini karena dimensi dan indikator-indikator sesuai dengan fenomena-fenomena yang ada pada obyek penelitian yang diteliti.

(1) Terkait variabel karakteristik masalah:

a. Tingkat kesulitan teknis dari masalah yang ada

b. Dalam hal ini dilihat bagaimana permasalahan yang terjadi, apakah termasuk permasalahan sosial yang secara teknis mudah diselesaikan atau masuk kategori masalah sosial yang secara teknis sulit untuk dipecahkan.

c. Tingkat kemajemukan dari kelompok sasaran

d. Hal ini menyangkut kelompok sasaran dari pembuatan suatu kebijakan atau dapat dikatakan masyarakat setempat yang dapat bersifat homogeni ataupun heterogen. Kondisi masyarakat yang homogen tentunya akan lebih memudahkan suatu program ataupun kebijakan diimplementasikan, sementara itu dengan kondisi masyarkat yang lebih heterogen akan lebih menyulitkan ataupun mendapat lebih banyak tantangan dalam pengimplementasiaannya.

e. Prosentase kelompok sasaran terhadap total populasi

f. Dalam artian bahwa suatu program atau kebijakan akan lebih mudah diimplementasikan ketika sasarannya hanyalah sekelompok orang tertentu 
atau hanya sebagian kecil dari semua populasi yang ada ketimbang kelompok sasarannya menyangkut seluruh populasi itu sendiri.

g. Cakupan perubahan perilaku yang diharapkan

h. Hal ini menyangkut akan hal bagaimana perubahan perilaku dari kelompok sasaran yang diharapkan dengan program yang ada. Sebuah kebijakan atau program akan lebih mudah diimplementasikan ketika program tersebut lebih bersifat kognitif dan memberikan pengetahuan. Sementara itu, program yang bersifat merubah sikap atau perilaku masyarakat cenderung cukup sulit untuk diimplementasikan seperti perda larangan merokok ditempat umum, dan lain-lain.

(2) Terkait variabel karakteristik kebijakan:

a. Kejelasan isi kebijakan

b. Sebuah kebijakan yang diambil oleh pembuat kebijakan haruslah mengandung konten yang jelas dan konsisten. Kebijakan dengan isi yang jelas akan memudahkan sebuah kebijakan dan akan menghindarkan distorsi atau penyimpangan dalam pengimplementasiannya. Hal ini dikarenakan jika suatu kebijakan sudah memiliki isi yang jelas maka kemungkinan penafsiran yang salah oleh implementor akan dapat dihindari dan sebaliknya jika isi suatu kebijakan masih belum jelas atau mengambang, potensi untuk distorsi ataupun kesalahpahaman akan besar.

c. Seberapa jauh kebijakan memiliki dukungan teoritis

d. Dukungan teoritis akan lebih memantapkan suatu aturan atau kebijakan yang dibuat karena tentunya sudah teruji. Namun, karena konteks dalam pembuatan kebijakan adalah menyangkut masalah sosial yang meski secara umum terlihat sama di setiap daerah, akan tetapi sebenarnya terdapat hal-hal yang sedikit banyak berbeda sehingga untuk mengatasi hal ini dapat dilakukan modifikasi saja.

e. Besarnya alokasi sumber daya finansial terhadap kebijakan tersebut

f. Hal yang tak dapat dipungkiri dalam mendukung pengimplementasian suatu kebijakan adalah masalah keuangan. Setiap program tentu memerlukan staf untuk melakukan pekerjaan-pekerjaan administrasi dan teknis, memonitor program, dan mengelola sumber daya lainnya yang kesemua itu memerlukan modal.

g. Seberapa besar adanya keterpautan dan dukungan antar berbagai institusi pelaksana.

h. Suatu program akan dengan sukses diimplementasikan jika terjadi koordinasi yang baik yang dilakukan antar berbagai instansi terkait baik secara vertikal maupun horizontal.

i. Kejelasan dan konsistensi aturan yang ada pada badan pelaksana

j. Badan pelaksana atau implementor sebuah kebijakan harus diberikan kejelasan aturan serta konsistensi agar tidak terjadi kerancuan yang menyebabkab kegagalan pengimplementasian.

k. Tingkat komitmen aparat terhadap tujuan kebijakan

1. Salah satu faktor utama kesuksesan implementasi sebuah kebijakan adalah adanya komitmen yang kuat dari aparatur dalam melaksanakan tugasnya. 
Komitmen mencakup keseriusan dan kesungguhan agar penerapan suatu peraturan ataupun kebijakan bisa berjalan dengan baik dan diterima serta dipatuhi oleh sasaran dari kebijaan tersebut.

m. Seberapa luas akses kelompok-kelompok luar untuk berpartisipasi dalam implementasi kebijakan

n. Sebuah program akan mendapat dukungan yang banyak ketika kelompokkelompok luar, dalam artian diluar pihak pembuat kebijakan seperti masyarakat ikut terlibat dalam kebijakan tersebut dan tidak hanya menjadikan mereka sebagai penonton tentang adanya suatu kebijakan ataupun program di wilayah mereka.

(3) Terkait lingkungan kebijakan:

a. Kondisi sosial ekonomi masyarakat dan tingkat kemajuan teknologi

b. Kondisi sosial ekonomi masyarakat menyangkut akan hal keadaan suatu masyarakat secara umum, mulai dari pendidikan, keadaan ekonomi, dan kondisi sosialnya yang secara sederhana dapat dikatakan kepada masyarakat yang sudah terbuka dan modern dengan masyarakat yang tertutup dan tradisional. Masyarakat yang sudah terbuka akan lebih mudah menerima program-program pembaharuan daripada masyarakat yang masih tertutup dan tradisional. Sementara itu, teknologi sendiri adalah sebagai pembantu untuk mempermudah pengimplementasian sebuah program. Teknologi yang semakin modern tentu akan semakin mempermudah.

c. Dukungan publik terhadap sebuah kebijakan

d. Dukungan publik akan cenderung besar ketika kebijakan yang dikeluarkan memberikan insentif ataupun kemudahan. Sebaliknya, dukungan akan semakin sedikit ketika kebijakan tersebut malah bersifat dis-insentif.

e. Sikap dari kelompok pemilih (constituency groups)

f. Kelompok pemilih yang ada dalam masyarakat dapat mempengaruhi implementasi kebijakan melalui berbagai cara, seperti; 1) kelompok pemilih dapat melakukan intervensi terhadap keputusan yang dibuat badan-badan pelaksana melalui berbagai komentar dengan maksud untuk mengubah kebijakan. 2) kelompok pemilih dapat memiliki kemampuan untuk mempengaruhi badan-badan pelaksana secara tidak langsung melalui kritik yang dipublikasikan terhadap kinerja badan-badan pelaksana, dan membuat pernyataan yang ditujukan kepada badan legislatif.

g. Tingkat komitmen dan keterampilan dari aparat dan implementor

h. Komitmen aparat pelaksana untuk merealisasikan tujuan yang telah tertuang dalam kebijakan adalah variabel yang paling krusial. Aparat badan pelaksana harus memiliki keterampilan dalam membuat prioritas tujuan dan selanjutnya merealisasikan prioritas tujuan tersebut.

\section{Penerapan Kebijakan Kawasan Tanpa Rokok di Taman Sempur Kota Bogor}

Taman Sempur Kota Bogor merupakan Taman Ikonik Kota Hujan yang terletak di Jl. Sempur Kaler No.4, Sempur, Kecamatan Bogor Tengah Kota Bogor. Posisinya bersebelahan dengan Kebun Raya Bogor di sisi utara dan sebelah barat dibatasi oleh Sungai Ciliwung. Ukuran lapangan Sempur kurang lebih sama dengan 
lapangan sepakbola tanpa gawang di kedua sisinya. Di dalam Taman Sempur terdapat Lapangan Sempur yang memiliki panjang lintasan lari 323,1 meter dengan luas permukaan 847 meter persegi. Pada zaman sebelum tahun 1900-an, Sempur merupakan kawasan yang diberi nama Kedung Halang yang meliputi Kampung Rambutan, Lebak Pilar Sempur Kidul, Sempur Kaler, Taman Kenacana, dan daerah sekitarnya. Sempur merupakan daerah pengembangan pemukiman Belanda yang awalnya terpusat pada Istana Bogor dan terus menyebar dan meluas ke wilayah sekitarnya.

Nama Sempur berasal dari sebuah nama jenis pohon. Konon, puluhan tahun yang lalu di daerah ini banyak ditumbuhi pohon-pohon Sempur. Pohon Sempur ini mempunyai buah yang bentuknya mirip dengan buah melon dengan ukuran yang relatif kecil, dan rasa buahnya mirip seperti rasa buah jambu air. Taman Sempur terdiri dari Taman kaulinan, dan Taman ekspresi serta diapit oleh lapangan basket, lapangan skateboard dan sarana wallclambing. Dengan demikian Taman Sempur dapat dikatakan sebagai area penyeimbang dari aktivitas manusia. Digdowiseiso dan Sugiyanto (2020) menyatakan bahwa: "Human activities that directly affect the environment act as the immediate causes of deforestation in which originate from land-use and directly impact upon forest cover". Sebagai ruang publik, Taman Sempur memiliki fasilitas untuk mendukung masyarakat agar dapat melakukan aktivitas di Taman Sempur. Fasilitas yang ada di Taman Sempur yaitu: Area panjat tebing, Jogging track, Area Paviing Block, Tempat Parkir, Pos Penjaga.

Dengan menggunakan model implementasi Mazmanian dan Sabatier (1983), didapatkan hasil penelitian tentang penerapan kebijakan kawasan tanpa rokok di Taman Sempur Kota Bogor sebagai berikut:

\section{Dimensi Karakteristik Masalah}

Karakteristik masalah dalam penerapan kebijakan kawasan tanpa rokok di Taman Sempur terkait aspek tingkat kesulitan teknis dari masalah yang ada adalah terbatasnya jumlah pengawas di Taman Sempur mengingat luasnya area Taman Sempur sebagai tempat berkumpulnya masyarakat. Kepala Seksi Promosi Kesehatan Pemberdayaan Dinas Kesehatan Kota Bogor mengatakan bahwa: "Kalau penerapan KTR di kota bogor, kalau menilai tingkat kepatuhan yang paling rendah memang tempat uтum salah satunya yang didalammnya taman, karena tempat berkumpulnya masyarakat, susah untuk mengontrol masyarakatnya, kalo tempat umum agak susah untuk memantaunya. Dan Taman Sempur juga area terbuka itu juga salah satu masalah yang dihadapi".

Terkait tingkat kemajemukan dari kelompok sasaran adalah pengunjung Taman Sempur merupakan masyarakat setempat yang dapat heterogen, sehingga menyulitkan ataupun mendapat lebih banyak tantangan dalam pengimplementasiaannya. Dalam konteks ini, kesenjangan pendidikan masih merupakan kendala utama dari heteregonitas masyarakat Indonesia. Kepala Seksi Promosi Kesehatan Pemberdayaan Masyarakat Dinas Kesehatan Kota Bogor mengatakan bahwa: "Untuk masyarakat, kebijakan ini dibuat untuk warga dan untuk orang-orang yang datang kekawasan itu, masyarakat yang berkujung bukan hanya dari warga bogor tetapi dari luar kota Bogor, kalo masyarakat bogor 
minimal sudah tau tentang kebijakan ini, kalo masyarakat di luar Bogor ada yang sudah tau ada yang belum. "

Terkait prosentase kelompok sasaran terhadap total populasi adalah banyaknya sasaran sekelompok orang tertentu dari semua populasi yang ada. Kepala Bidang Pengendalian Operasional Satpol-PP Kota Bogor mengatakan bahwa: "Khusus Taman Sempur ya, memang agak sulit untuk penerapan kebijakannya karna emang Taman Sempur kawasan pengembangan, hanya emang kendalaya adalah, masih banyak yang berfikir area terbuka, karna pada awanya Peraturan Daerah tentang KTR tahun 2009 area terbuka diperbolehkan untuk merokok tapi harus dibaca kembali kawasan sempur yaitu kawasan olahraga, dan memang di area terbuka tidak di sediakan untuk area khusus merokok, ya gimana ya kalo kami sediakan tempat khusus merokok misalkan beberapa meter dari taman yang menjadi kawasan tanpa tetep aja nanti asepnya muncul dari sana, karna kan bukan tempat tertutup kalo dalam presentasenya $50 \%$ penerapannya masih ada yang belum sadar tentang beretika merokok".

Terkait cakupan perubahan perilaku yang diharapkan adalah belum optimalnya perubahan perilaku dari kelompok sasaran yang diharapkan dengan program yang ada. Penjaga Taman Sempur atau Park Ranger mengatakan bahwa: "Alhamdulilah ada perubahan sedikit lambat launnya ada perubahan, ya walaupun perubahannya masih belum banyak, tapi alhamdulilah lah ada perubahan, khususnya taman kaulinan yang banyak anak-anak sudah berkurang, perubahan yang ada sekarang mah pengunjung sudah tidak berani merokok, ini mah yang maap-maap ya paham tentang aturan tapi masih ada weh yang berani kaya di daerah paving block masih ada aja teh yang merokok. Sedikit berkurang teh karna adanya Peraturan Daerah." Sementara Kepala Seksi Promosi Kesehatan Pemberdayaan Dinas Kesehatan Kota Bogor mengatakan bahwa: "Kalo perubahan belum lihat, karna kawasan tanpa rokok di Taman Sempur baru tahap sosialisasi, kalo perubahan harus adanya tindakan sebelum adanya tindakan dilakukan pembinaan terlebih dahulu, jadi masih berproses masih tahap sosialisasi”.

\section{Dimensi Karakteristik Kebijakan}

Karakteristik kebijakan dalam penerapan kebijakan kawasan tanpa rokok di Taman Sempur terkait aspek kejelasan isi kebijakan adalah bahwa isi Perda Kota Bogor Nomor 10 Tahun 2018 tentang Kawasan Tanpa Rokok sebagian besar belum diketahui secara jelas oleh masyarakat atau Pengunjung Taman Sempur sehingga terjadi distorsi atau penyimpangan dalam pengimplementasiannya. Padahal Perda Kota Bogor Nomor 10 Tahun 2018 tentang Kawasan Tanpa Rokok telah secara jelas memberikan uraian tentang kawasan tanpa rokok di kawasan-kawasan tertentu. Salah satu informan dari masyarakat yang berkunjung ke Taman Sempur mengatakan bahwa: "Sudah tau sih mba, sudah lumayan baik sih, lumayan berkurang masyarakat yang merkok disini, sebelumnya mah banyak yang ngerokok kalo saya sendiri sih hari ini belum ngeliat langsung masyarakat yang ngerokok. Kalo pemerintah mensosialisasikannya secara langsung sih belum pernah liat, ya paling dari speaker yang berapa menit sekali suka dihimbau gaboleh ngerokok 
disekitar Taman Sempur, terus ya dengan plang yang kaya di bawah itu mba gaboleh ngerokok, sisha, sama vape."

Terkait aspek seberapa jauh kebijakan memiliki dukungan teoritis adalah masih kurang jelasnya informasi yang disampaikan kepada masyarakat atau pengunjung Taman Sempur dalam memahami ketentuan yang berlaku di Taman Sempur. Salah satu informan dari masyarakat yang berkunjung ke Taman Sempur mengatakan bahwa: "Tau kalo disini gaboleh ngerokok, kalo kebijakannya tauya dari plang yang ada disana kak, nah disana saya ngeliat gaboleh ngerokok, vape dan sisha masih berjalan kurang baik soalnya masih banyak yang ngerokok,biasanya banyak ngerokok ya daerah daerahh sini pavng block, sebenrnya sih kayanya ga boleh disini, terus ya emang keamanannya kurang kaya penjaganya kurang untuk menengur masyarakat yang merokok, dulu sering banget ditegur, saya aja ditegur kalo ngerokok disini tapi sekarang jarang sih. Cara pemerintah ngasih taunya ya, kalo secara langsung sih belum tapi kalau disini beberapa menit sekali suka ada penguman dari speaker gaboleh ngerokok dikawasan taman disini kak dsini dan ada plang plang yang maksud saya tadi kak juga sih kak".

Terkait aspek besarnya alokasi sumber daya finansial terhadap kebijakan adalah masih rendahnya sumber daya pengelola Taman Sempur untuk melakukan pekerjaan-pekerjaan administrasi dan teknis, memonitor program, dan mengelola sumber daya lainnya dalam penerapan kebijakan kawasan tanpa rokok di Taman Sempur. Kepala Seksi Promosi Kesehatan Pemberdayaan Dinas Kesehatan Kota Bogor mengatakan bahwa: "Ada alokasinya untuk Kawasan Tanpa Rokok, Alokasi dana Kawasan Tanpa Rokok dari APBD, kalo anggaran khusus tidak ada, tapi anggaran Kawasan Tanpa Rokok itu berdiri sendiri tidak mencampur dengan anggaran lainnya, untuk KTR di Kota Bogor dibantu oleh NJO Notice walaupun ga memeberikan dana secara langsung tapi membantu dalam keberhasilan Kawasan Tanpa Rokok di kota bogor." Sementara Kepala Bidang Pengendalian Operasional Satpol-PP Kota Bogor mengatakan bahwa: "Kadang saya juga dilematis ya karena disatu sisi untuk penegakan KTR dibiayai oleh beacukai Kota Bogor sebagian dari $A P B D$ kota Bogor, APBD untuk KTR berdiri sendiri tidak gabung dengan anggaran lainnya sekitar 20\% Anggaran Daerah di alokasikan untuk KTR ini".

Terkait aspek seberapa besar adanya keterpautan dan dukungan antar bebagai institusi pelaksana adalah sudah cukup baik. Kepala Seksi Promosi Kesehatan Pemberdayaan Dinas Kesehatan Kota Bogor mengatakan bahwa: "Ada pastinya, untuk Taman Sempur berkordinasi dengan Park Ranger, Satpol - PP, Hakim, Jaksa dan lain-lainnya kalo untuk penegakan KTR, karna tindakan yang dilakukan untuk para pelanggar KTR yaitu yaitu Tipiring tindak Pidana Ringan dan alokasi dana tersebut dari Dinas dan Satpol PP biasanya Tipiring dilakukan 6 kali dalam setahun." Sementara Kepala Bidang Pengendalian Operasional Satpol-PP Kota Bogor mengatakan bahwa: "Ya ada, dengan Dinkes, Hakim, Jaksa, Kepolisian karna untuk membuat sadar para pelanggar kami melakukan Tipiring, tindak pidana ringan yang melakukan ya institusi tersebut, tapi di Taman Sempur belum dilakukan tipiring karna terbentur biaya, karna biayanya lumayan besar harus bayar hakim, jaksa dan lain-lainnya". 
Terkait aspek kejelasan dan konsistensi aturan yang ada pada badan pelaksana adalah sudah cukup baik. Kepala Bidang Pengendalian Operasional Satpol-PP Kota Bogor mengatakan bahwa: "Regulasi yang mengatur Kawasan Tanpa Rokok di Taman Sempur Peraturan derah Nomor 10 Tahun 2018 tentang Kawasan Tanpa Rokok, Taman Sempur merupakan tempat umum lainnya, sebelumnya pada Peraturan Daerah Nomor 12 tahun 2009. Untuk konsistensi aturan ya sudah berjalan dengan konsisten karna kebijakan ini sudah berjalan kurang lebih sepuluh tahun dan dari awal kebijakan Taman Sempur sudah termasuk Kawasan Tanpa Rokok".

Terkait aspek tingkat komitmen aparat terhadap tujuan kebijakan adalah sudah cukup baik karena adanya komitmen yang cukup kuat dari aparatur dalam melaksanakan tugasnya. Kepala Seksi Promosi Kesehatan Pemberdayaan Dinas Kesehatan Kota Bogor mengatakan bahwa: "Tujuan dari adanya kebijakan ini yaitu untuk melindungi perokok pasif, khususnya ditaman kan tempat berkumpul keluraga ada anak-anak yang harus dilindungi dari asap rokok, kalau untuk komitmen ya kami berkomitmen untuk mencapai tujuan kebijakan tersebut dengan konsisten dalam mensosialisasikan kebijakan tersebut, kami sudah mensosialisikan dari tahun 2009 dengan media sosial, media cetak, spanduk tanda yang ada di kawasan KTR, tetapi untuk KTR di Taman Sempur emang belum ada tindak langsung." Sementara Penjaga Taman Sempur atau Park Ranger mengatakan bahwa: "Kalo untuk tujuan mah ya untuk melindungi masyarakat yang ga ngerokok, kaya anak-anak kan banyak disini, ibu hamil yang ga boleh kena asap rokok, kalo komitmen mengawasi kebijakan KTR di Kota Bogor mah mungkin sudah baik ya, tapi kalau di Taman Sempur ini belum ada tindakan langsung dari aparat yang lebih berwenang, kalau kami mah bisanya hanya menegur ga bisa untuk menindak langsung".

Terkait aspek seberapa luas akses kelompok-kelompok luar untuk berpartisipasi dalam implementasi kebijakan adalah sudah cukup baik karena masyarakat ikut terlibat dalam kebijakan tersebut dan tidak hanya menjadikan mereka sebagai penonton tentang adanya suatu kebijakan ataupun program di wilayah mereka. Kepala Bidang Pengendalian Operasional Satpol-PP Kota Bogor mengatakan bahwa: "Ada pihak lain selain Dinas yang membantu, kaya komunitas atau LSM tapi untuk nama komunitas atau LSM nya saya lupa namanya apa, nanti coba mbanya ke Dinas Kesehatan untuk minta nama komunitas atau LSM yang membatu adanya KTR." Sementara Kepala Seksi Promosi Kesehatan Pemberdayaan Dinas Kesehatan Kota Bogor mengatakan bahwa: "Ada steakholder yang membantu ya NJO Notice tadi, membantu kami untuk menunjang keberhasilan KTR di Kota Bogor bentuk bantuannya seperti mengadakan seminar untuk mensosialisasikan KTR dan kami tidak mengeluarkan biaya".

\section{Dimensi Lingkungan Kebijakan}

Lingkungan kebijakan dalam penerapan kebijakan kawasan tanpa rokok di Taman Sempur terkait aspek kondisi sosial ekonomi masyarakat dan tingkat kemajuan teknologi adalah sudah cukup baik karena masyarakat atau pengunjung Taman Sempur umumnya sudah terbuka dalam menerima program-program pembaharuan dari Pemerintah Daerah meskipun masih ada sebagian kecil 
masyarakat atau pengunjungnya yang masih bersifat tertutup dan tradisional terhadap penerapan kawasan tanpa rokok di Taman Sempur. Penjaga Taman Sempur atau Park Ranger mengatakan bahwa: "Iya mba menujang, maap - maap ya mba kalo masyarakat yang memiliki pendidikan bagus biasanya lebih beretika untuk merokok teh engga asal ngerokok aja karna kan ini udah aturannya teh, nah yang maap mba pendidkannya kurang kami tegur malah mereka kadang marah kekami, padahal kami menegurnya sudah dengan 35 mba, senyum, sapa ,salam dan teknologi juga menunjang kalau ga salah ini mah ya teh, pemerintah melakukan sosialisasi dengan lewat teknologi jadi kalau masyarakat yg paham dengan teknologi mah harusnya bisa tau dari sana”. Sementara Kepala Bidang Pengendalian Operasional Satpol-PP Kota Bogor mengatakan bahwa: "Ya pastinya, karna maaf ya kalo masyakarat yang merokok maaf pendidikannya kurang kalo kami tegur pasti marah dan pernah ada yang bilang ya hak saya untuk ngerokok, rokok-rokok saya, tapi kalo orang yang punya pendidikan tinggi pasti lebih bijak kalau mau merokok lebih beretika ketika mau merokok ga disembarang tempat".

Terkait aspek dukungan publik terhadap sebuah kebijakan adalah belum sepenuhnya baik karena kebijakan kawasan tanpa rokok yang dikeluarkan memberikan dis-insentif dalam penerapannya. Salah satu informan dari masyarakat atau pengunjung Taman Sempur mengatakan bahwa: "Kurang mendukung saya mah kak, karena kan saya perokok di Taman Sempur disini dilarang untuk merokok tapi kami ga di sediakan unntuk merokok, yang gimana ya mba harusnya kan dilarang tapi ga disediakan, dan kan taman ini ruang terbuka, kalo saya ngerokok juga asepnya suka kebawa angin kak saya ngerasa juga asepnya enggak langsung terhidup sama orang lain."

Terkait aspek sikap dari kelompok pemilih (constituency groups) adalah sudah cukup positif, karena secara umum masyarakat atau pengunjung Taman Sempur menyetujui adanya kebijakan kawasan tanpa rokok. Salah satu informan dari masyarakat atau pengunjung Taman Sempur mengatakan bahwa: "Mendukung banget soalnya, kami sebagai warga bisa menikmati kegiatan-kegiatan yang ada disini seperti olahraga, senam, berkumpul dengan keluarga disini tanpa asap rokok, dan saya bukan perokok juga mba jadi saya sangat mendukung, dengan adanya kebijakan ini saya dan orang-orang yang tidak merokok merasa terlindungi dari asap rokok".

Terkait aspek tingkat komitmen dan keterampilan dari aparat dan implementor adalah sudah cukup baik karena adanya komitmen dan keterampilan yang cukup kuat dari Pengelola Taman Sempur untuk merealisasikan tujuan yang telah tertuang dalam kebijakan kawasan tanpa rokok di Taman Sempur. Kepala Seksi Promosi Kesehatan Pemberdayaan Dinas Kesehatan Kota Bogor mengatakan bahwa: "Regulasi yang mengatur dalam kebijakan Kawasan Tanpa Rokok yaitu peraturan Daerah nomor 10 tahun 2018 tentang Kawasan Tanpa Rokok sebelumnya regulasi yang Peraturan Daerah nomor 12 tahun 2009, regulasi tersebut direvisi karena mengikuti perkembangan zaman yang ada dan ada beberapa point yang ditambahkan tadinya tidak boleh merokok saja, sekarang tidak boleh merokok elektrik atau vape dan sisha. Kalau ditanya konsisten aturan tersbut, ya sudah konsisten karna dari awal di terbitkan kebijakan ini sudah terdapat delapan 
kawasan dan Taman Sempur sudah termasuk karena kawasan olahraga, dan pada perubahan Peraturan Daerah yang ada sempur menjadi kawasan KTR dalam kategori tempat umum lainnya."

\section{SIMPULAN}

Berdasarkan hasil penelitian dan pembahasan yang telah diuraikan pada sub bab di atas dapat disimpulkan bahwa penerapan kebijakan kawasan tanpa rokok di Taman Sempur Kota Bogor belum sepenuhnya efektif. Dari dimensi karakteristik masalah, kendala yang dihadapi antara lain: (a) keterbatasan jumlah pengawas di Taman Sempur; (b) tingginya tingkat kemajemukan dari kelompok sasaran; (c) banyaknya sasaran sekelompok orang tertentu dari semua populasi yang ada; dan (d) belum optimalnya perubahan perilaku dari kelompok sasaran yang diharapkan dengan program yang ada. Dari dimensi karakteristik kebijakan, hambatan yang dihadapi antara lain: (a) sebagian besar isi Perda Kota Bogor Nomor 10 Tahun 2018 tentang Kawasan Tanpa Rokok belum diketahui secara jelas oleh masyarakat atau Pengunjung Taman Sempur; (b) masih kurang jelasnya informasi yang disampaikan kepada masyarakat atau pengunjung Taman Sempur dalam memahami ketentuan yang berlaku di Taman Sempur; dan (c) masih rendahnya sumberdaya pengelola Taman Sempur untuk melakukan pekerjaan-pekerjaan administrasi dan teknis, memonitor program, dan mengelola sumberdaya lainnya dalam penerapan kebijakan kawasan tanpa rokok (Juanita, 2012) di Taman Sempur. Dari dimensi lingkungan kebijakan, kendala/hambatan yang dihadapi adalah belum optimalnya dukungan publik terhadap kawasan tanpa rokok di Taman Sempur

\section{Rekomendasi}

Dari simpulan di atas, rekomendasi yang dapat diberikan dalam penelitian ini adalah perlunya evaluasi penerapan kebijakan kawasan tanpa rokok di Taman Sempur Kota Bogor, baik dari dimensi karakteristik masalah, karakteristik kebijakan, dan lingkungan kebijakan. Secara teknis, Pengelola Taman Sempur perlu melakukan upaya-upaya sebagai berikut:

a. Menambah jumlah aparat dalam kegiatan pengawasan di Taman Sempur.

b. Meningkatkan sosialisasi dan sarana larangan merokok kepada masyarakat atau pengunjung.

c. Memberikan sanksi yang tegas kepada masyarakat atau pengunjung.

\section{DAFTAR PUSTAKA}

Ali, Lukman. (1995). Kamus Besar Bahasa Indonesia. Jakarta: Balai Pustaka.

Badudu, J.S. dan Sutan Mohammad Zain. (1996). Kamus Umum Bahasa Indonesia. Jakarta: Pustaka Sinar Harapan.

Dunn, William N. (2000). Pengantar Analisa Kebijakan Publik. Yogyakarta: Gadjah Mada Press. 
Digdowiseiso, Kumba, and Eko Sugiyanto. (2020). The Effects of Multinational Companies on Deforestation: The Building Block or Stumbling Block. Journal of Environmental Management and Tourism, (Volume XI, Spring), 1(41): $5-11$.

Friedrich, Carl J. (1971). Political Decision-Making, Public Policy And Planning, Institute Of Public Administration of Canada.

Juanita. (2012). Kebijakan Kawasan Tanpa Rokok. Jurnal Kebijakan Kesehatan Indonesia, 01 (02), 112-119

Mazmanian, Daniel H., dan Paul A. Sabatier. (1983). Implementation and Public Policy. New York: Harper Collins.

Peraturan Daerah Kota Bogor Nomor 12 Tahun 2009 tentang Kawasan Tanpa Rokok, Kemudian diubah menjadi Peraturan Daerah Nomor 10 Tahun 2018 tentang Kawasan Tanpa Rokok.

Ripley, Randall B., and Grace A. Frankin. (1982). Policy Implementation and Bureaucracy. Chicago : The Dorsey Press.

Sugiyanto, Eko. (2018). Pengendalian Dalam Organisasi. Edisi Revisi, Jakarta: LPU-Universitas Nasional.

Van Meter, D. S., \& Van Horn, C. E. (1975). The Policy Implementation Process: A Conceptual Framework. Administration \& Society, 6(4), 445-488. https://doi.org/10.1177/009539977500600404.

Wahab, Solichin A. (2012). Analisis Kebijakan dari Formulasi ke Penyusunan Model-Model Implementasi Kebijakan, Jakarta: Bumi Aksara. 